\title{
IMPLEMENTATION OF CORPORATE SOCIAL RESPONSIBILITY (CSR) PROGRAM AT PT. ANUGERAH LANGKAT MAKMUR
}

\section{IMPLEMENTASI PROGRAM CORPORATE SOCIAL RESPONSIBILITY (CSR) PADA PERUSAHAAN PT. ANUGERAH LANGKAT MAKMUR}

\author{
Chiquitita Qinthar Azura*, Iwan Setiawan \\ Program Studi Agribisnis, Fakultas Pertanian, Universitas Padjajaran \\ *Email: Chiquitita17001@mail.unpad.ac.id \\ (Diterima 29-07-2021; Disetujui 15-12-2021)
}

\begin{abstract}
Corporate social responsibility (CSR) is a form of management defined by an ethical and transparent relationship between the company and all stakeholders (relevant parties) in the form of community development, environmental and cultural preservation for future generations, diversity and the promotion of reducing social problems. As a matter of fact, the community feel cared for through PT Anugerah Langkat Makmur's (PT ALAM) CSR activities, whereas the company only produces semi-finished products or has no direct relationship with end consumers. Qualitative designed research using case study methods aims to determine the types and implementation of CSR programs at PT ALAM. Primary data collection was collected with in-depth observation and interview techniques, while secondary data was collected through desk study from Public Relation of PT ALAM. The collected data was analyzed descriptionally. The results show that PT ALAM has implemented corporate social marketing, corporate philanthropy, and socially responsible business practice program. CSR is implemented every year and has been internalized in its business structure. PT ALAM has implemented CSR programs in the form of education, construction of facilities and infrastructure, as well as socio-cultural and religious.
\end{abstract}

Keywords: Corporate Social Responsibility (CSR), Implementation

\begin{abstract}
ABSTRAK
Corporate social responsibility merupakan bentuk manajemen yang didefinisikan oleh hubungan etis dan transparan antara perusahaan dengan semua pemangku kepentingan (pihak terkait) dalam bentuk pembangunan masyarakat, pelestarian lingkungan dan budaya untuk generasi masa depan, keanekaragaman dan promosi pengurangan masalah sosial. Secara riil, masyarakat merasa diperhatikan melalui kegiatan CSR PT Anugerah Langkat Makmur, padahal perusahaan tersebut hanya menghasilkan produk setengah jadi atau tidak memiliki keterkaitan langsung dengan konsumen akhir. Penelitian yang didesain secara kualitatif dengan metode studi kasus ini bertujuan untuk mengetahui jenis dan implementasi program CSR di PT ALAM. Pengumpulan data primer dilakukan dengan teknik observasi dan wawancara mendalam, sedangkan data sekunder dikumpulkan melalui desk study dari Humas PT ALAM. Data yang terkumpul dianalisis secara deskriptif. Hasil penelitian menunjukkan bahwa berdasarkan jenisnya, PT ALAM telah menerapkan corporate social marketing, corporate philanthropy, dan socially responsible business practice. CSR diimplementasikan setiap tahun dan sudah diinternalisasikan dalam struktur bisnisnya. PT ALAM telah melaksanakan program CSR dalam bentuk pendidikan, pembangunan sarana dan prasarana, serta sosial budaya dan keagamaan.
\end{abstract}

Kata kunci: Corporate Social Responsibility (CSR), Implementasi 


\section{IMPLEMENTASI PROGRAM CORPORATE SOCIAL RESPONSIBILITY (CSR) \\ PADA PERUSAHAAN PT. ANUGERAH LANGKAT MAKMUR \\ Chiquitita Qinthar Azura, Iwan Setiawan}

\section{INTRODUCTION}

Palm oil is a very strategic agricultural product commodity with a production of around 4.09 tons per hectare per year (Poku, 2002). The high productivity of this commodity results in palm oil to be very competitive and it is widely used in various products, such as the food industry, cosmetics, health products, biofuels, and biodiesel (Perindustrian, 2007). Currently, the demand for palm oil is very high, with the largest consuming countries being India and China, while the main producers are Indonesia and Malaysia with a market share of around $85 \%$ (Wicaksono, Rifin, \& Pahan, 2018).

Indonesia as one of the largest palm oil producers in the world has a great opportunity to continue to increase its production. However, various environmental and social problems that have arisen along with the development of the palm oil industry have become a challenge for this business actor. The emergence of pressure from various parties, ranging from the state to the international community, has caused stakeholders in the palm oil industry to start trying to create a sustainable palm oil industry.
Around 1992, the concept of sustainable corporate development emerged by having a positive impact on the surrounding environment, namely Corporate Social Responsibility (CSR) which aims to bridge the needs of surrounding community with the interests of the company (Doh, Luthans, \& Slocum , 2016).

At this present moment, most companies have revised their paradigm from just making profit for shareholders (owners) to participating in efforts to meet the expectations of society. These expectations can include taking responsibility for the company's activities that can damage the environment and to safeguard the welfare of the community. The main purpose of implementing CSR for companies in Indonesia is to contribute a number of company resources, to improve social welfare, and to comply with the law (Orlitzky, Schmidt, \& Rynes, 2003).

One of the initiatives taken in Indonesia to create a sustainable palm oil industry is the establishment of Indonesian Sustainable Palm Oil (ISPO) which is a policy of the Indonesia's Ministry of Agriculture to increase the competitiveness of Indonesian palm oil in the world market through a commitment 
to pay attention to environmental issues (Nanggara, Rosalina, Kartika, \& Setyawan, 2017). The basis of the ISPO principles and criteria is the concept of The Triple Bottom Line (Elkington, 1997). The concept holds that if a company wants to maintain its existence, it must pay attention to the 3Ps, namely profit, people, and planet.

According to the Center for Agricultural Data and Information Systems (2019), in Indonesia around $40.6 \%$ of the palm oil industrial area is managed by the people, $55 \%$ of oil palm plantations are controlled by the private sector and the remaining $4.4 \%$ is managed by government-owned plantations. In palm oil industry, all administrator must participate in ensuring the sustainability of this industry. Whereas, when observed from the proportion of oil palm ownership, the private sector is the largest administrator so that it has a crucial role in the development of the palm oil industry. Therefore, this has become the impetus for conducting research on private plantation company.

PT Anugerah Langkat Makmur (PT ALAM) is a private company engaged in the palm oil industry since 1988 . Since its official establishment, PT ALAM has been actively carrying out social responsibility in the community around the business unit. However, these responsibilities are still in the nature of charity, philanthropy and alms from the owner of the company. In this study, an analysis of the implementation of CSR at PT ALAM was carried out on the basis of curiosity regarding the implementation of CSR which was originally philanthropic and then shifted to a wider scope. Therefore, this study aims to examine the types of CSR programs implemented at PT ALAM.

\section{RESEARCH METHODS}

This research was conducted at PT Anugerah Langkat Makmur. The subject in this study is the superintendent of CSR at PT ALAM. The object of this research is the implementation of the Corporate Social Responsibility program at the PT ALAM which is located in Kampung Lama, Besitang, Langkat Regency, North Sumatra. This study uses a qualitative design with a case study method.

Informants in this study are internal offices that hold the CSR division with data sources consisting of primary data and secondary data. Primary data collection in this study was obtained from survey results to PT ALAM informants 
using interview, observation and documentation techniques. For secondary data, obtained by literature study from Public Relations in the form of a CSR report at the company PT ALAM.

In this study, the data analysis technique refers to the analysis stages according to Miles and Huberman (1994) namely data collection, data reduction, data presentation, conclusion drawing and verification.

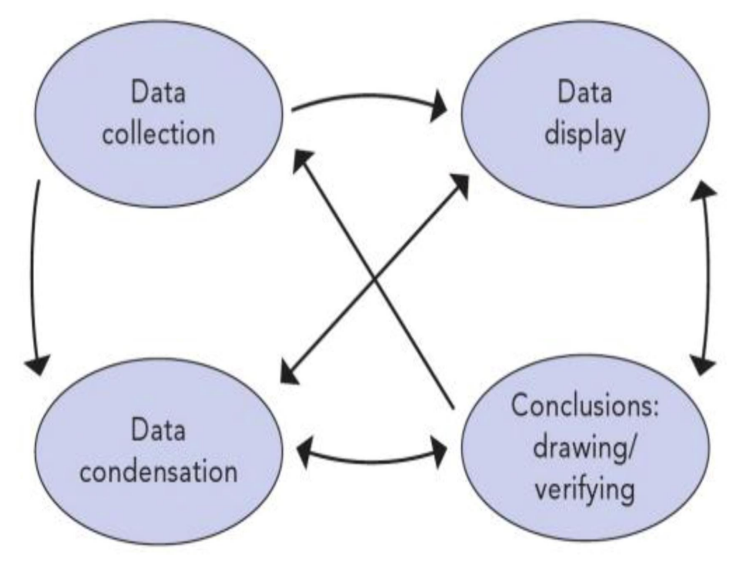

Figure 1. Qualitative Data Analysis Mechanisms (Miles \& Huberman, 1994)

\section{RESULTS AND DISCUSSION}

\section{Company Background}

Started in 1982 with the initial planting of oil palm seedlings with an area of 7.5 ha in Besitang District, Langkat Regency, North Sumatra. For Langkat Regency, currently the plantation area has reached approximately 2000 ha. There are plans to continue to expand the land with a larger area following the existing potential. Then in early 1988 a company incorporated under the name PT Anugerah Langkat Makmur was established. PT Anugerah Langkat Makmur is an agribusiness company that focuses on the oil palm plantation sector and palm oil mills.

In 2009 the company received ISO 9001:2000 international certification on the quality management system from the TUV-Rheinland certification body. Continued in 2010, there was an upgrade of certification to ISO 9001:2008. This is an astounding achievement for the company, where the certification shows the recognition of international standard organizations for the quality management system carried out by the company for the maintenance and management of oil palm plantations. In 2014, PT ALAM started the company's internal mapping until finally in July 2018 it received ISPO (International Sustainable Palm Oil) certification.

\section{Type of CSR Program}

In determining the classification of CSR program types, the researcher used the identification by Kotler and Lee in 2005. There are several types of 
programs including Cause Promotions, Cause Related Marketing, Corporate Social Marketing, Corporate Philanthropy, Community Volunteering, and Socially Responsible Business Practice. Based on these six types of programs, PT ALAM has implemented three of them:

\section{Corporate Social Marketing}

The program has a primary focus on behavioral change and the intensity of its outcomes. In order to change public behavior, its activities can be related to several things such as improving the health sector, ecology, transportation, and in non-profit organizations.

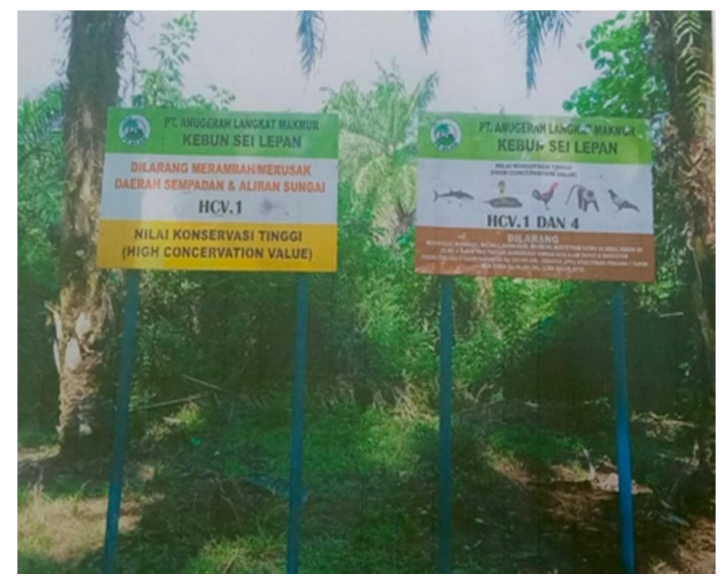

Figure 2. Signs Forbidden to Destroy Plants and Kill Animals at Sei Lepan Garden Locations

In this program activity, there is a campaign built by PT ALAM related to the environment by making a signboard that prohibits killing animals surround the area because the existing animals can contribute to the fertility of oil palm land.
With this sign, the company expects that the surrounding community will be aware of the preservation of the existing flora.

\section{Corporate Philanthropy}

The implementation of this program has a direct impact on solving social problems in the local community because the company contributes directly through social activities to certain community donations in the form of cash grants, supporting facilities, scholarships or in-kind services.

Activities that have been carried out by PT ALAM in executing this program, for example, is giving monthly donations for mosques and churches, mosque nadzir during Eid, donations of money for iftar at mosques, donations for gravediggers, and assistance for local teachers' fees.

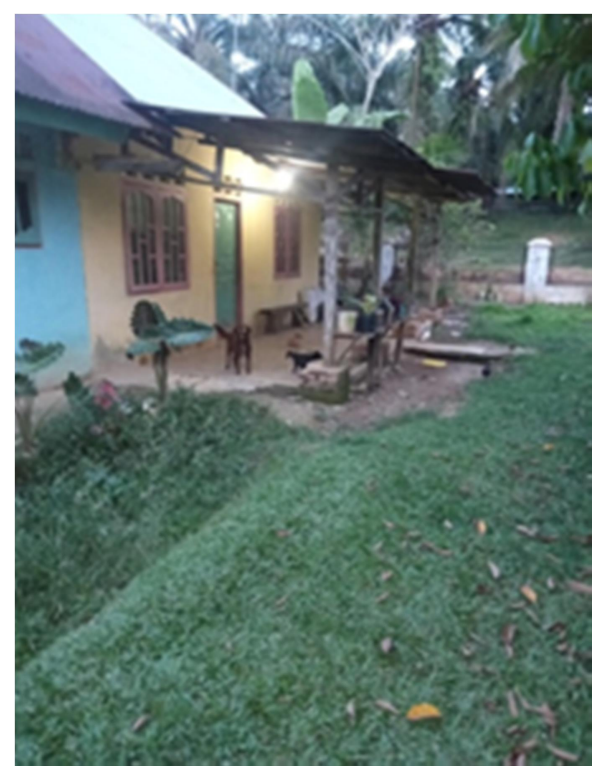

Figure 3. CSR in the Religious Sector (Construction of a Mosque in Sei Lepan District, Langkat Regency) 


\section{IMPLEMENTASI PROGRAM CORPORATE SOCIAL RESPONSIBILITY (CSR) \\ PADA PERUSAHAAN PT. ANUGERAH LANGKAT MAKMUR \\ Chiquitita Qinthar Azura, Iwan Setiawan}

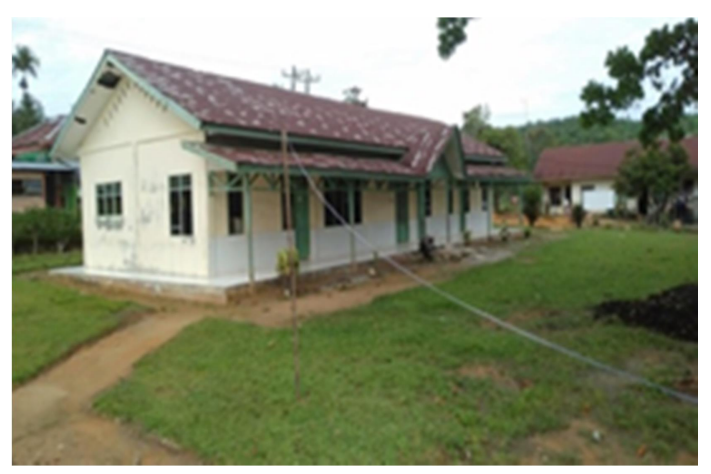

Figure 4. CSR in the Religious Sector Construction of a Pastor's House in Sei Lepan District)

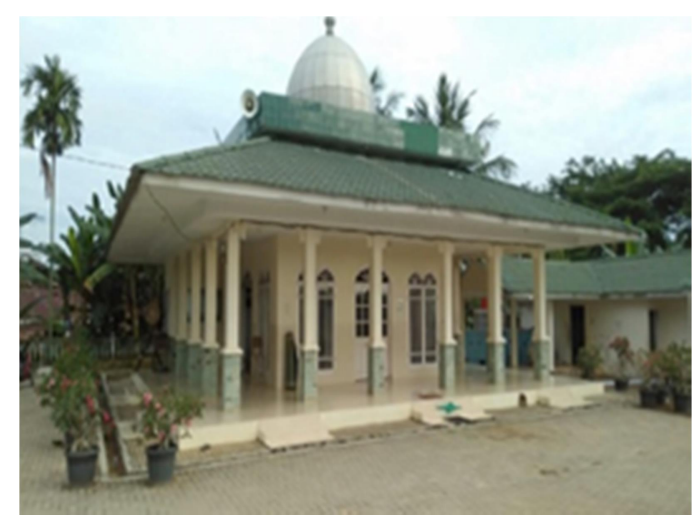

Figure 5. CSR in Education Sector (Construction of Madrasah Schools in Sei Lepan Subdistrict)

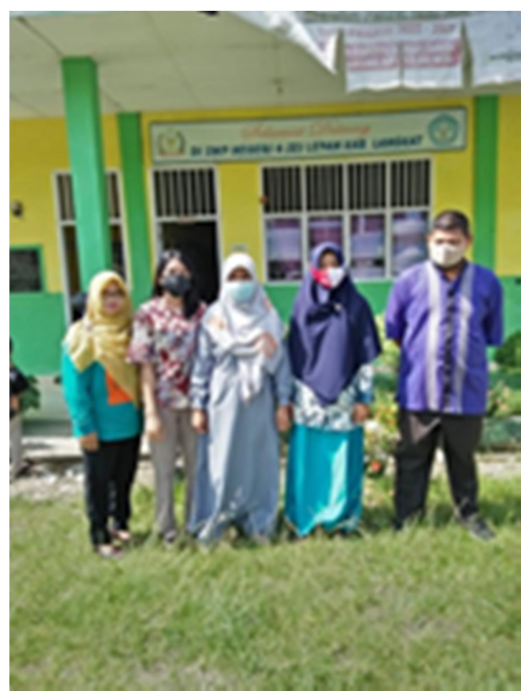

Figure 6. CSR in Education Sector (Construction of Junior High School Buildings in Sei Lepan Subdistrict and donated to Langkat Regency Government to Become SMPN 4 Sei Lepan)
3. Socially Responsible Business Practice

In this program, the company encourages investment business activities by supporting well-thought-out social activities with a long-term commitment because this program can change the relevant internal policies to improve community welfare and protect the environment. In the implementation of this program, PT ALAM helped provide land with a borrow-to-use system to assist PDAM Tirta Wampu's plan, which is the water treatment program for clean water for the community in the Langkat area. This program shows that there is a correlation between companies to improve people's welfare.

In addition, PT ALAM carries out developing process improvements by supporting and carrying out waste reduction activities with waste water treatment in palm oil mills. This activity is carried out by making ponds to reduce the concentration of organic waste substances so that they do not pollute water bodies. This program shows the company's correlation to protect the environment.

PT ALAM also applies the 3R (Reduce, Reuse, Recycle) concept that has been included in the company's 
environmental permit by maximizing palm oil waste so that it has economic value that nothing is wasted or "zero waste" by recycling empty bunches which are then used as organic fertilizer.

Another activity in this program is to support employee welfare or developing programs to support employee well being, in which the welfare of employees at PT ALAM is also considered by the existence of assisted internal cooperatives, namely Berkat Anugerah Jaya (KUD BAJA) and Rahma Tani (KUD RATA). At the end of palm oil age planting, the tree must be uprooted. During this period, the cooperatives assisted provide financial assistance so that the employees can also be helped economically. Then, the funds during the uprooting period will be returned by the employee with an installment system. This proves that there is a correlation with the welfare of society.

Meanwhile, based on findings in the field directly, three other types of programs namely, cause promotions, cause related marketing, and community volunteering have not been implemented by PT ALAM because this company produces semi-finished products. The sales results are not directly to consumers which does not have a large enough scope. In implementing a cause promotion program, it should be considered and implemented when the company has access to the target market easily, and when the promotion objectives are related to the products issued by the company (Kotler \& Lee, 2005). Therefore, it can be concluded that the cause promotions program in general can only be applied to companies whose scope is already widespread or even national.

The next program that has not been able to be carried out by PT ALAM is Cause Related Marketing (CRM) because this company only processes oil palm fruit into Crude Palm Oil (CPO). According to Kotler and Lee (2005), CRM activities have the potential to be carried out if the company has a product that has high appeal or has a mass market and is similar to Cause Promotions that supports public awareness, but the difference in CRM is that its contribution is based on consumer response. Therefore, it can be concluded that this type of program is possible for PT ALAM if the company produces palm oil not only up to CPO.

The Community Volunteering Program is the last type of activity that 


\section{IMPLEMENTASI PROGRAM CORPORATE SOCIAL RESPONSIBILITY (CSR) \\ PADA PERUSAHAAN PT. ANUGERAH LANGKAT MAKMUR \\ Chiquitita Qinthar Azura, Iwan Setiawan}

has not been carried out routinely by PT ALAM. Volunteer activities carried out by employees by giving their time to help local community organizations and communities targeted by the company. Guidance was carried out at the beginning of the establishment of the factory to smallholder farmers by providing oil palm seeds and knowledge on how to plant, fertilize and harvest properly so that the results were maximized with the same standards as factory farmers. This program contains the development of volunteer programs that must be appropriate to real social, economic, and environmental problems to suit the company's business needs (Kotler \& Lee, 2005).

\section{CSR Implementation at PT ALAM}

"aggressive company" where the promotion level is low while the performance is high. This can happen because PT ALAM only carries out promotions to companies above it (business partners) by maintaining the quality of $\mathrm{CPO}$ and maintaining good relations with buyers.

Companies in Indonesia implement CSR based on laws and regulations from the government. However, there is no CSR implementation model (Rumambi, Kaligis , Tangon, \& Marentek, 2018). In order to properly distribute CSR assistance, the management of PT ALAM has determined the flow or process of social responsibility activities with the fulfillment of several stages as follows:

1. The community submits a proposal to the office of the business unit in the

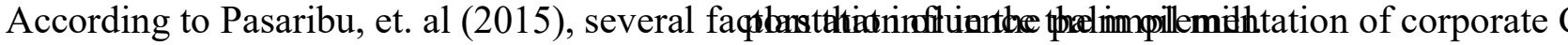

The concept of implementing CSR according tTh\&uld,nBitestesitaffandw(1)shomed(2008), generally ha have already begun and can be seen from proposal to the Corporate Secretary the CSR organizational structure at PT (CS) at the Board of Directors' Office ALAM until the publication of the annual in Medan.

report on social responsibility activities.

3. CS staff will contact the plantation or

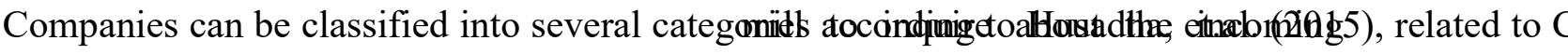

PT ALAM is included in the "reformist company" where the profit and CSR budget are quite high. Meanwhile, if it is categorized on the implementation objectives, PT ALAM is included in the proposal so that it becomes a record to be submitted to the Head of the CS.

4. The Head of the CS will submit to the director with inputs from the business 
unit (whether this proposal is feasible or not to be assisted).

5. If approved, the director will write the nominal amount of assistance on the approval sheet and at the same time affix his signature.

6. The Head of the CS will resubmit the approved proposal to the CS Staff for further request for funds to be made to the finance department by attaching an approval sheet that has been signed by the director.

7. Funds that have come out of the finance departement will be transferred by CS staff to the business unit as well as contacting the staff in the business unit to collect the funds at the nearest bank.

8. Unit staff will contact the community who submitted the initial proposal and once the funds are submitted, a receipt will be issued.

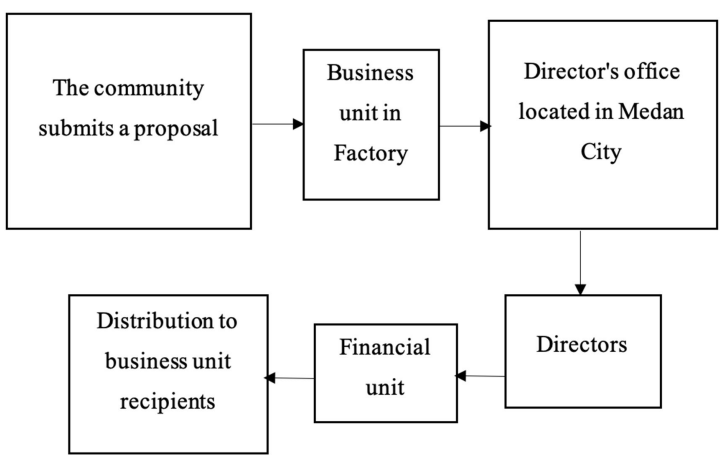

Figure 7. Flow of CSR Activities

\section{CONCLUSION AND SUGGESTIONS}

\section{Conclusion}

By looking at the results of research on PT Anugerah Langkat Makmur, the authors can conclude that the implementation of CSR programs includes three types among the six types that have been classified by Kotler and Lee. The types of programs implemented are: Corporate Social Marketing, Corporate Philanthropy, and Socially Responsible Business Practice. PT ALAM as a company engaged in the oil palm plantation sector and palm oil mills has implemented CSR programs every year covering the fields of Education, Facilities and Infrastructure Development Programs and Socio-Cultural and Religious Programs.

The

CSR

program implementation process is carried out in two ways, namely, direct assessment by PT ALAM's management to the field for distribution of CSR funding assistance and or the recipient of the assistance can submit a proposal to the business unit office in the plantation or in the palm oil mill. From the results of the implementation, it can be seen that PT ALAM carries out social responsibility activities seriously based on commitments marked by the seriousness 


\section{IMPLEMENTASI PROGRAM CORPORATE SOCIAL RESPONSIBILITY (CSR) \\ PADA PERUSAHAAN PT. ANUGERAH LANGKAT MAKMUR \\ Chiquitita Qinthar Azura, Iwan Setiawan}

where these activities have been internalized in the structure and business planning so that it can be proven that CSR is carried out not just a formality.

\section{Suggestions}

Based on the conclusions above, the researcher provides several suggestions that are expected to be input to all parties implementing CSR. The suggestions referred to include the following:

1. The implementation of CSR should be expanded the in PT. Anugerah Langkat Makmur so that other types of programs can be implemented in the future. The most feasible at this time is the implementation of the Community Volunteering program which can encourage employees to volunteer time by helping local community organizations or communities related to oil palm, and so on so that staff's commitment to CSR implementation can be further increased. .

2. It is hoped that in the future the implementation of CSR will be able to spread to other forms of activity other than the education program, facilities and infrastructure development program, and socio- cultural and religious program so that it can be felt by a wider scope of society.

\section{REFERENCES}

Auld, G., Bernstein, S., \& Cashore, B. (2008). The New Corporate Social Responsibility. Annual Review of Environment and Resources 2008, 33, 413-435.

Doh, J., Luthans, F., \& Slocum, J. (2016). The World of Global Business 1965-2015 Perspectives on the 50th Anniversary Issue . Journal of World Business, 1-5.

Elkington, J. (1997). Cannibals With The Fork. Oxford: Capstone Publishing Limited.

Husadha, C., Syafitri , A., \& Oktaviana , B. (2015). Pengaruh Agresivitas Pajak Terhadap Corporate Social Responsibility (CSR) (Studi kasus pada PT Astra Agro Lestari, Tbk periode tahun 2001-2005). Jurnal Ilmiah Akuntansi dan Manajemen, 9-17.

Kotler, P., \& Lee, N. (2005). Corporate Social Responsibility : Doing The Most Good For Your Company and Your Cause. Hoboken: John Wiley $\&$ Sons, Inc.

Miles, M., \& Huberman, A. (1994). Qualitative Data Analysis : An Expanded Sourcebook. California: Sage.

Nanggara, S., Rosalina, L., Kartika, R., \& Setyawan, A. (2017). Enam Tahun ISPO. Bogor: Forest Watch Indonesia.

Orlitzky, M., Schmidt, F., \& Rynes, S. (2003). Corporate Social and Financial Performance: A MetaAnalysis. Organization Studies, 403-441. 
Pasaribu, A., Affifuddin, S., \& Helmi, S. (2015). The Effect Of Corporate Social Responsibility (CSR) Programs At The Palm Oil Mill Companies On Regional Development In South Labuhan Batu District . International Journal of Management Sciences and Business Research, 4(1).

Perindustrian, K. (2007). Gambaran Sekilas Industri Minyak Kelapa Sawit . Jakarta: Sekretariat Jenderal.

Pertanian, K. (2019). Outlook Kelapa Sawit. Jakarta: Pusat Data dan Sistem Informasi Pertanian Sekretariat Jenderal - Kementerian Pertanian.

Poku, K. (2002). Small-Scale Palm Oil Processing in Africa. $F A O$
Agricultural Services Bulletin 148. Retrieved from http://www.fao.org/3/Y4355E/y435 5e00.htm\#Contents

Rumambi, H., Kaligis , S., Tangon, J., \& Marentek, S. (2018). The Implementation Model of Corporate Social Responsibility (CSR): An Indonesian Perspective. International Journal of Academic Research in Business and Social Sciences, 8(10), 761-773.

Wicaksono, D. A., Rifin, A., \& Pahan, I. (2018). The Sustainability of Three Indonesian Palm Oil Business Entities. Manajemen \& Agribisnis, 249-249. 